\title{
Role of the Food Supply Chain Stakeholders in Achieving UN SDGs
}

\author{
Ilija Djekic ${ }^{1, *} \mathbb{C}$, Laura Batlle-Bayer ${ }^{2}$, Alba Bala $^{2}$, Pere Fullana-i-Palmer ${ }^{2}\left(\mathbb{D}\right.$ and Anet Režek Jambrak ${ }^{3}(\mathbb{C}$ \\ 1 Faculty of Agriculture, University of Belgrade, 11080 Belgrade, Serbia \\ 2 UNESCO Chair in Life Cycle and Climate Change, ESCI-UPF, 08003 Barcelona, Spain; \\ laura.batlle@esci.upf.edu (L.B.-B.); alba.bala@esci.upf.edu (A.B.); pere.fullana@esci.upf.edu (P.F.-i.-P.) \\ 3 Faculty of Food Technology and Biotechnology, University of Zagreb, 10000 Zagreb, Croatia; arezek@pbf.hr \\ * Correspondence: idjekic@agrif.bg.ac.rs
}

check for updates

Citation: Djekic, I.; Batlle-Bayer, L.; Bala, A.; Fullana-i-Palmer, P.; Jambrak, A.R. Role of the Food Supply Chain Stakeholders in Achieving UN SDGs. Sustainability 2021, 13, 9095. https://doi.org/ $10.3390 /$ su13169095

Academic Editor: Giada La Scalia

Received: 29 June 2021

Accepted: 11 August 2021

Published: 13 August 2021

Publisher's Note: MDPI stays neutral with regard to jurisdictional claims in published maps and institutional affiliations.

Copyright: (c) 2021 by the authors. Licensee MDPI, Basel, Switzerland. This article is an open access article distributed under the terms and conditions of the Creative Commons Attribution (CC BY) license (https:// creativecommons.org/licenses/by/ $4.0 /)$.

\begin{abstract}
This paper gives an overview of main food supply chain stakeholders and their role in achieving the UN Sustainable Development Goals (SDGs). As this supply chain is global, playing a significant role in feeding the world, a deeper analysis of 17 SDGs, their targets and indicators reveals numerous direct and indirect connections with various SDGs. To perform such an overview, the authors investigated the link between the main stakeholders of the chain (farmers, food processors, food traders and consumers) with UN SDGs. In parallel, the authors explored the roles of policymakers, inspection services, certification bodies and academia in supporting these SDGs. In spite of numerous papers, calculations and estimations, discussion and media coverage, the authors believe that only the tip of the iceberg has been revealed. Based on this overview, the authors emphasize SDG 2-Zero Hunger and SDG 12-Responsible Consumption and Production as the most dominant for the food supply chain. In parallel, the achievement of SDG 17-Partnerships for the Goals will enable deeper intertwining of the goals and all stakeholders in the food supply chain continuum. Additional efforts are needed to pave the way for fulfilling the targets of the UN SDGs and exceeding expectations of all stakeholders.
\end{abstract}

Keywords: farmers; food processors; food traders; food consumers; UN SDGs

\section{Introduction}

In 2015, the United Nations adopted the 2030 Agenda for sustainable development to end poverty and achieve sustainability worldwide. This 15-year plan consists of 17 Sustainable Development Goals (SDGs) with a list of 169 SDG Targets, and progress towards these Targets are to be tracked by 232 unique Indicators [1]. Since the adoption of the SDGs, many discussions have been raised regarding the role of food systems due to its high contribution to society, economy and environment. In July 2021, a Food Systems pre-summit took place in Rome with participants from 190 countries (both in person and virtual) and outlined national pathways to address multiple aspects of food systems in relation to UN SDGs "based on the best science and reflecting local and national realities within a global context" [2]. In September 2021, the UN Secretary-General António Guterres will convene the Food Systems Summit as part of the Decade of Action to achieve the Sustainable Development Goals (SDGs) by 2030. The Summit will launch bold new actions to deliver progress on all 17 SDGs, each of which relies, to some degree, on healthier, more sustainable and equitable food systems [3].

This opens a wide perspective for economists, scientists, academia and food industry stakeholders to recognize their role in achieving the SDGs. Deeper analysis of the SDGs, targets and indicators shows that food systems have more indirect than direct connections, as eight SGDs are in direct correlation with the food, as reported by the Food and Agriculture Organization [4]. Nevertheless, limited attempts have identified the role of food systems in achieving the UN SDGs from a holistic food supply chain perspective. 
Herrero et al. [5] have connected them with selected case studies highlighting the role of technological innovations. Country-based approaches were observed in several studies, such as the one of Brown et al. [6], analyzing food policy of India, that of and Siegel and Bastos Lima [7], analyzing the framework of agri-food governance in three South American countries. Concerning SDG-based studies, several have analyzed the impact of food systems transitions on SDG 2 [8,9]. Hence, the current article aims at being the first overview on recognizing the role of the main food supply chain stakeholders and anticipate their connections with the UN SDGs. Food supply chains consist of several links such as agricultural production, food processing, food distribution, retail, consumption and finally, disposal of food waste [6]. As supply chains also depend on the physical-geographical distance of the chain (from primary production to the place of consumption), they can be also classified as "local" and "global" [10]. Depending on the driver, food supply chains can be driven by large retailers, cooperatives, global multinational companies or have short supply chains [11]. However, in general, an average food supply chain is composed of four major actors: farmers, food processors (including all types of B2B food processors), food traders (consisting of distribution and retail) and consumers, although chains may vary based on transformation of food within core processes [12]. When the food supply chain is analyzed from a wider perspective, secondary stakeholders emerge, such as media, policymakers, inspection services, academia and scientific community, competitors and non-governmental organizations (NGO) $[11,13,14]$. Hence, this article considers primary and secondary stakeholders (Table 1).

Table 1. Selected stakeholders in the food supply chain.

\begin{tabular}{ll}
\hline Primary Stakeholders & Secondary Stakeholders \\
\hline Farmers & Policymakers and governments \\
Food processors & Inspection services and certification bodies \\
Food traders & Scientific community \\
Food consumers & Other: NGOs and media \\
\hline
\end{tabular}

The objective of this paper was to provide an overview of the main primary and secondary stakeholders in the food supply chain and how they are related with the UN SDGs. More specifically, we connected UN SDG targets with primary stakeholders (Section 2), and further deployed impacts of farmers, food processors, food traders and food consumers on achieving UN SDGs (Section 3). Section 4 provides an insight on how policymakers and governments, inspection services and certification bodies, the scientific community and other secondary stakeholders affect UN SDGs from a food perspective. Finally, we graphically depicted the food supply chain in terms of main facts and figures and UN sustainable development goals.

\section{Materials and Methods}

In order to perform an overview on connecting UN SDGs and the key stakeholders of the food systems, at first glance, it was obvious that a literature review with various combinations of different key words (food production/food systems/food supply chain) in various scientific databases will raise different results (i.e., in ScienceDirect search engine for "food production and UN sustainable development goals", over 15,000 results were reported, and for "food systems and UN sustainable development goals", over 20,000 results were also revealed). As this topic is heterogeneously dispersed through various scientific publications (research and review articles, book chapters, conference papers, editorials, etc.), the authors focused attention of this overview on specific UN SDGs to enlighten the connection between the goals and links in the food supply chain.

To specify the goals of interest, the co-authors of this paper participated in a session by ranking relationships between UN SDGs and four main links of the chain using the Delphi method to stimulate and synthesize the opinions of these experts. We used a simplified thematic analysis approach using the following steps: (i) familiarization with 
UN SDGs/targets; (ii) define direct/indirect codes; (iii) analyze targets and (iv) assign codes [15].

The Delphi session was organized online (due to the travelling restrictions caused by the COVID-19 pandemic) and the authors of this paper gave their opinion on the type of connection of targets with stakeholders with the aim to reach consensus. All 169 targets have been analyzed in terms of their direct or indirect connection with one of the four stakeholders of the supply chain. If no connection was observed, the target was categorized as "other". The Delphi method is often used to elicit experts' knowledge and achieve consensus [16]. The results of such an analysis are depicted in Figure 1. The outcome shows that 52 targets are directly (12) or indirectly (40) connected with the food supply chain (Supplementary Material). There were no holdouts for any of the targets. Authors confirmed that all targets have been adequately assigned for each actor in the food supply chain. This figure served as a tool in classifying articles and performing this overview. Herrero et al. [5] had a different approach and analyzed the connection of 232 indicators with eight UN SDGs clearly outlined by the FAO [4] as opposed to the remaining nine UN SDGs.

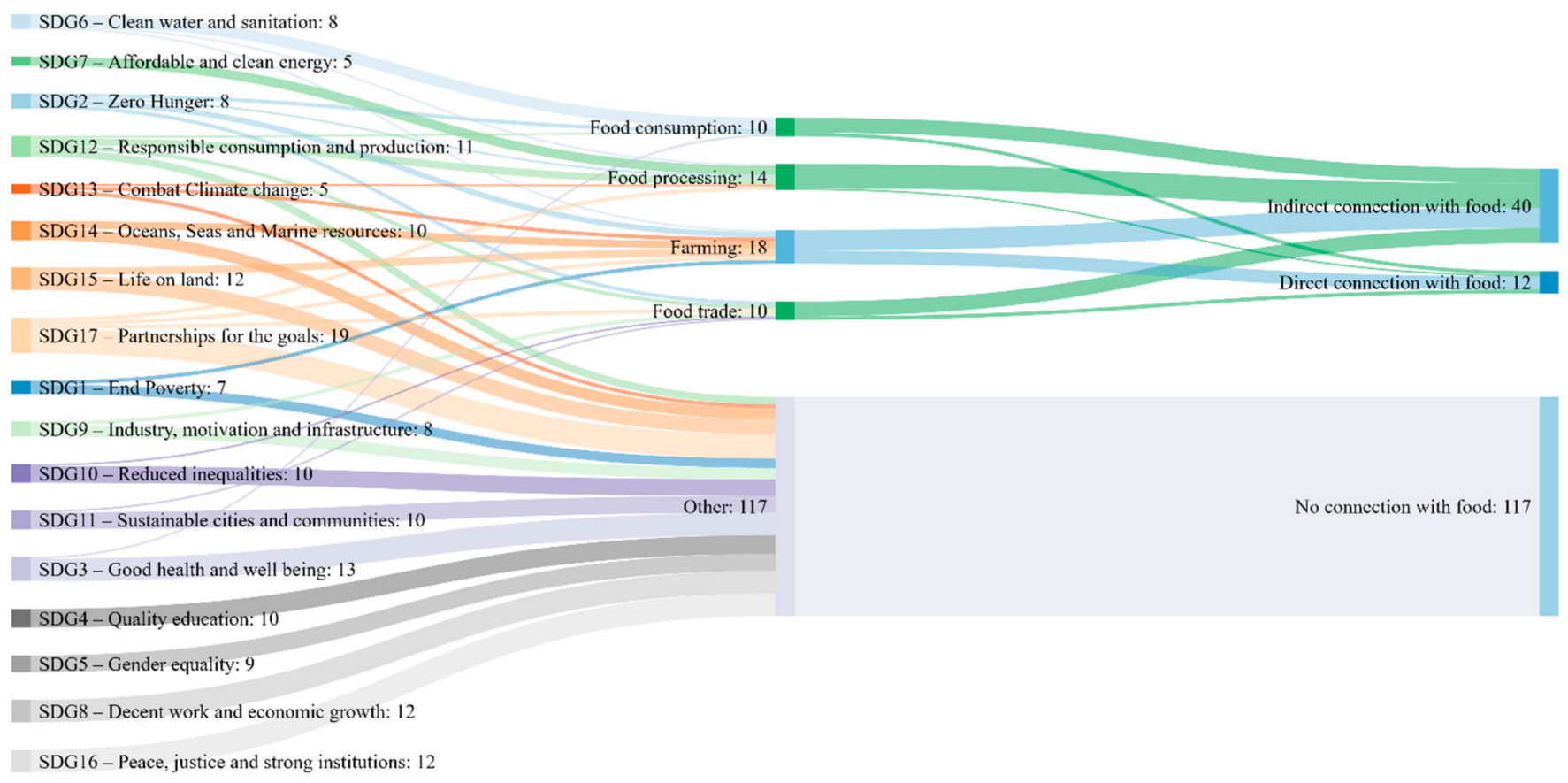

Figure 1. Sankey chart showing connection between UN SDGs and four links of a food supply chain.

\section{Food Supply Chain and UN SDGs}

\subsection{Impact of Farmers on Achieving UN SDGs (and Vice Versa)}

Agricultural practice, as the first link of the supply chain, plays a crucial role to meet the food demand of a growing global population. While food production tripled between 1960 and 2015 due to land expansion and intensification, it has caused (severe) environmental impacts. Food production uses $70 \%$ of the freshwater withdrawals and about $40 \%$ of land and is responsible for about $23-33 \%$ of the global GHG emissions [17-19]. Hence, the challenge remains on how to produce in a sustainable way-by enhancing resource-use efficiency (SDGs 6, 12,14,15) and mitigating/adapting to climate change (SDG 13) -in order to achieve global food security (SDG 2) and improve the livelihood and well-being of farmers (SDGs 1, 2, 3), especially of smallholders, who produce about $75 \%$ of all food [20].

In this regard, the FAO [21] states the need to transform current agricultural systems towards a more "holistic" food production systems, such as agroecology, climate-smart agriculture and conservation agriculture. This transformation has multiple effects on the 
SDGs. For instance, Arouna et al. [22] reported higher yields for new varieties of rice, which increased the income (SDG 2; on average, USD 3.9 per year per capita) and reduced poverty (SDG 1 ; between $18 \%$ and $24 \%$ ) of small-scale farmers in sub-Saharan Africa. However, the level of adoption of changes in farming practices has been lower than the ones needed to achieve food security, according to Thornton et al. [23], who evaluated the state of the changes in agricultural practices of 6300 smallholders in 21 countries. Technological improvements in agriculture also pave the way for ensuring food security associated with SDG 2, such as the design of a smart honey supply chain that improved food security and food safety, and reduced honey fraud [24]. This smart agricultural system was based on blockchain technology.

Transforming farming systems is also crucial to take action on climate change (SDG 13). Food production is an important contributor to greenhouse gas (GHG) emissions, and enhancing its efficiency can reduce $40 \%$ the GHG emissions per food produced [25]. In addition, farmers must adapt to current changing climate effects such as variations in mean temperatures, global water cycles associated with modified precipitation patterns and occurrence of extreme weather events [26]. Climate change can reduce $70 \%$ of crop yields by 2030 [27], and therefore, adapting to climate change is needed to enhance food security (SDG 2) and reduce poverty (SDG 1) among small-scale farmers [28,29].

Land access and ownership is a fundamental factor for farmers to decide on changing their agricultural practices. Charoenratana and Shinohara [30] stated that "farmers' increased land stability will raise confidence to invest in the land and a wider variety of professional opportunities that will produce enough to allow stable food security of farming households". Hence, they concluded that land security has a crucial role to improve food security. In this regard, Villano et al. [31] also reported the relationship between land access and higher productivity in livestock and crop-livestock farming systems in Ghana; Rashid [32] found a positive correlation between land tenure security, agricultural credit and rice productivity in Tanzania. In addition, the access to land and other resources are key factors to achieve gender equality (SDG 5) in farming systems, as only $5-30 \%$ of the cultivated land is owned by women in developing countries [33].

\subsection{Impact of Food Processors on Achieving UN SDGs (and Vice Versa)}

To achieve sustainability, food processors should transform their conventional food processing systems through designing resource-efficient innovations and minimizing residues by promoting reusability and material recycling. One focus should be on clean water and sanitation (SDG 6). Food processing is an important stage of the food supply chain that requires high-quality (potable) water [34]. Water is either used as an ingredient for production or for cleaning and sanitation as a main prerequisite in good hygiene practice programs [35]. Moreover, there are many types of wastewaters in food processing, and many challenges that can be accomplished by innovative nonthermal technologies, used to oxidase and decontaminate water to be used afterwards. Such water is dependent on pollutant loadings from food/food processes with wastewater treatment in place [35].

Concerning affordable and clean energy (SDG 7), food processing should use renewable energy sources. In addition, food processing can indirectly impact the industry, motivation and infrastructure (SDG 9), with digitalization, optimization and innovation of the food processing industry, including Industry 4.0 and the establishment of high quality and efficient infrastructures. By efficient planning, optimization and digitalization, resource use can be reduced along the whole food supply chain, productivity and employment can increase and food systems can benefit from value addition. The combination of achieving targets set in SDGs 2, 6 and 7 represent three sectors that are very closely linked with the water-food-energy nexus [4].

Concerning responsible consumption (SDG 12), innovation towards more sustainable food packaging can extend the shelf life of fresh produce, and, subsequently reduce food waste [36], and the associated environmental and economic cost. Food processing is key in achieving food safety and in obtaining safe products. Some researchers propose the 
application of nonthermal and advanced thermal processing as a tool to assure food safety by using safe, green, clean and energy efficient technology [37,38]. Those smart and efficient productions will end in smart factory production, smart land use for bio production [39] and with low GHG emissions that impact climate change (SDG 13). Augustin et al. [40] identify the critical role of food processing in food and nutrition security (SDG 2), striving towards sustainable diets (SDG 12) and reducing food losses (SDG 12) for achieving resource use efficiency (SDGs 6, 7).

\subsection{Impact of Food Traders on Achieving UN SDGs (and Vice Versa)}

Food traders play a key role in ensuring that safe and healthy food is accessible and affordable (SDGs 2, 3). Considering the fact that more than 50 million people will be undernourished by 2050 due to climate change (SDG 13), the present international food trade practice needs to be modified [41]. Climate change directly influences regions and food production modifying trade patterns [42]. Although climate change increases the role of trade in reducing the risk of hunger (SDG 2), it does not always provide optimal options in terms of types of food traded. Therefore, promotion of changing (reducing) tariffs and all kinds of institutional and infrastructural barriers may decrease the negative impact to over 20 million undernourished [41].

Climate change also has an impact on transportation systems, causing delays, rerouting and re-scheduling, reduced speed, pressure on tires, stress on infrastructure/vehicles, road/railway closures and vehicle instability [43]. Connection of food transportation and climate change highlights the need for reducing GHG emissions from the vehicles as well as the promotion of low carbon fuels (SDG 7) striving towards climate friendly transportation policies [44]. This may be connected with SDG 9, highlighting the need for building sustainable infrastructure as well as combating climate change (SDG 13).

Comparing the sustainability of local vs. global food systems is complex. Several studies (i.e., Coley et al. [45]) have used the concept of "food-mile" and linked it with climate change (SDG 13). Food-mile is calculated as distance that a certain type of food travels from where it is grown/raised to where it is purchased by the consumer and/or end user. It takes into account all raw materials, their quantities, locations where they were grown/raised, distance to the food producer as well as transportation of the final product to (all) traders [46]. In most cases, imported foods do not emit higher GHG emissions than local food products, but this might depend on the selected environmental impact, such as reported by Payen et al. [47]. In this regard, Farmery et al. [48] highlights the inadequacy of this food-mile concept as a sustainable metric, and Schmitt et al. [49] concluded that the health and socio-economic dimensions are the key ones for local products, after comparing the sustainability of 14 local and global foods, considering five dimensions (environmental, economic, social, health and ethics).

Some food commodities require cold chains associated with maintaining optimal time/temperature ratio during transportation involving specific trucks and refrigerants [50]. Climate change impact linked with food trade is associated with the use of refrigerants needed in cold chains as this is important for achieving prescribed food safety levels [51,52]. These impacts clearly identify a need for climate action (SDG 13) associated with GHG emissions and ozone layer depletion linked with storage/retail [53]. One approach is shifting from hydrofluorocarbon refrigeration systems to systems with lower impact on climate change, in line with the EU legislation [54]. In addition, a simulation of sustainability of perishable food supply chains revealed that perishability of food may increase various environmental impacts up to $120 \%$ [55]. However, good storage practices in terms of industry innovation (SDG 9) have potential in combating climate change (SDG 13) [56]. Internet of Things as a concept (SDG 9) enables better transportation traceability and monitoring as well as optimizing energy consumption (SDG 7) and GHG emissions (SDG 13) [57].

Traders can take advantage of different types of food labels to communicate and promote healthy food products in their commercial establishments. International ISO standards present environmental labels as "claims which indicate the environmental aspects of 
a product or service" [58] with the possibility to communicate environmental information at different levels and different formats [59]. Environmental labels (aligned with food labels as mandatory legal requirements) must consider all relevant impacts of a product's life cycle and use a reliable and verifiable evaluation method. However, going one step further and aligned with the SDGs, information of products should not be only environmental but also provide social and potentially economic benefits (Figure 2). For the sake of simplicity, we will call it here as "sustainable labelling". In this sense, there are a huge number of organizations, promoted by groups of producers, retailers, nongovernment organizations or public authorities, that have developed their own voluntary sustainable labelling schemes to provide information to consumers about certain aspects of the food they buy or its production method [60]. In all of them, there are four common goals: (1) they provide information that consumers otherwise might not have; (2) they provide information in a format that is understandable and quickly comprehensible for most consumers; (3) its use and the verification system behind foster trust of consumers; and (4) they empower consumers. The labels allow consumers to express their individual value perception of product characteristics. Consumers can compare different product quality attributes and which characteristics they prefer [61]. In this sense, it is worth mentioning a couple of recent labels that have appeared in the European market: Nutri-Score, combining nutritional and health issues, and Eco-Score, showing the environmental impact of food (SDG 6, 7, 13); both of them bring added values to food choices (SDG 12) [62]. All the above-mentioned labelling programs, from ISO standards to the most recent Eco-Score and Nutri-Score, aim to encourage food choices associated with lower environmental impact and responsible consumption. The vast availability of schemes developed [63] have increased market-based incentives for environmentally friendly products and production processes.

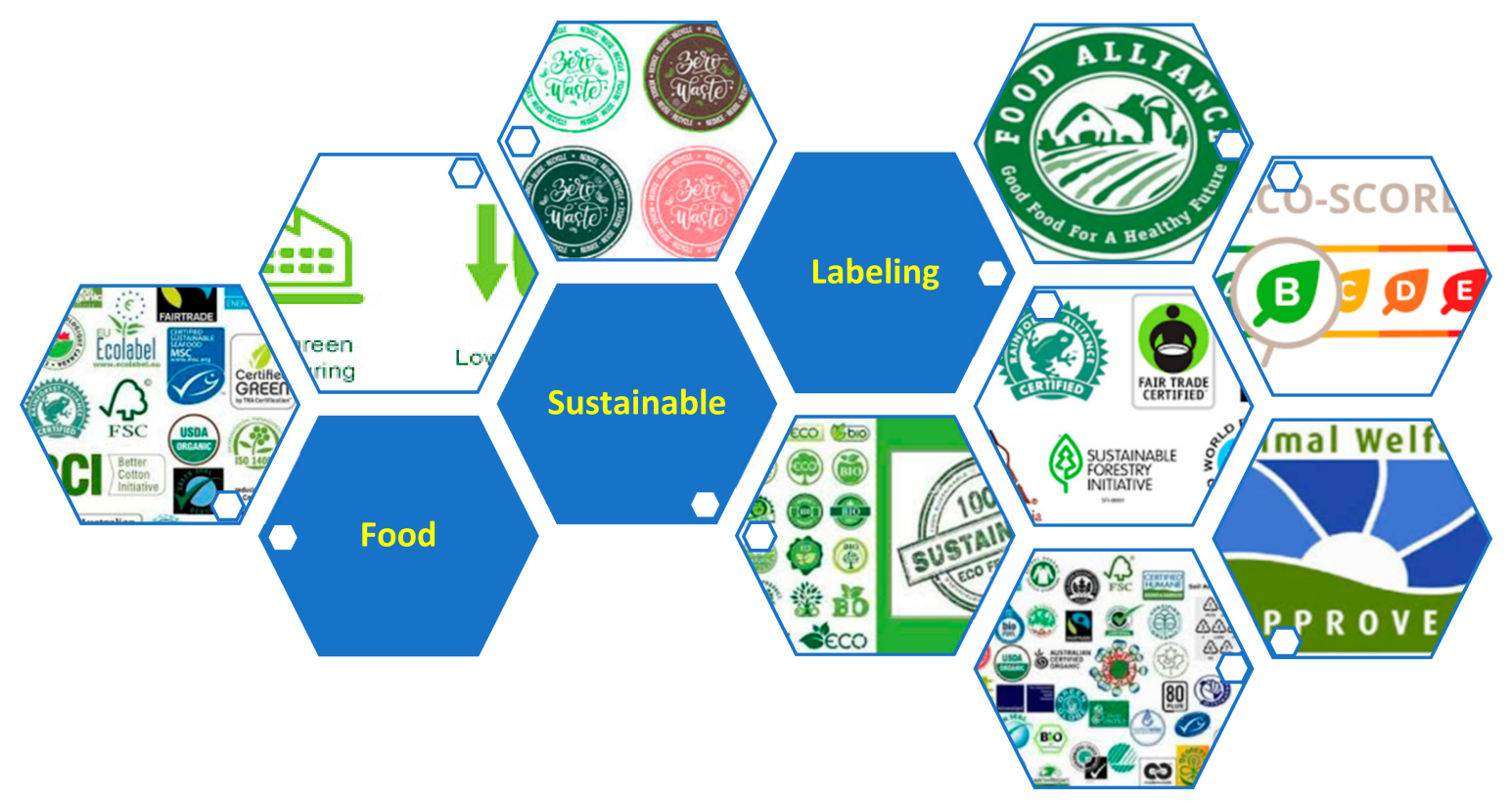

Figure 2. Some of labels for food produced and declared as sustainable.

\subsection{Impact of Food Consumers on Achieving UN SDGs (and Vice Versa)}

As defined by the FAO, "sustainable diets are those diets with low environmental impacts which contribute to food and nutrition security and to healthy life for present and future generations. Sustainable diets are protective and respectful of biodiversity and ecosystems, culturally acceptable, accessible, economically fair and affordable; nutritionally adequate, safe and healthy; while optimizing natural and human resources". Hence, they affect several SDGs (i.e., 2, 3, 12-15), but the world is far from attaining sustainable targets related to diets. In 2019, 60 million people went hungry in 5 years, 9\% of the global 
population ( 690 million people) was undernourished ( 840 million by 2030 , if no changes take place) and two billion people (30\% of the global population) experienced hunger or had irregular access to nutritious and sufficient food [64]. In addition, the FAO related the prevalence of hunger with the low affordability of healthy diets, reporting that 3 billion people cannot afford the cheapest healthy diet.

Food consumption patterns also contribute to health (SDG 3) and climate change (SDG 13). With higher incomes and urbanization, global food consumption patterns shift to diets with higher intake of animal-based products, processed and sugar-sweetened beverages, which are related to overweight and obesity, and higher GHG emissions. If this trend of global dietary transition prevails, the GHG emissions related to the production of these diets will increase $80 \%$ of food production by 2050 [65].

In the past 5 years, a large amount of literature has reported the environmental benefits of adopting healthy and sustainable diets (i.e., [66-69]), showing that dietary shift is a key strategy for climate action. Still, the pressure on changing dietary habits as a result of mainly environmental impacts is more explored in scientific models than observed in everyday life [50]. Therefore, the fundamental question remains on how to encourage people to adopt sustainable diets (SDG 2, 3, 12, 13).

The availability and accessibility of food to daily life of people, known as food environments (FAO, 2016), are key to determine food choices and, ultimately, consumers' diet quality [70]. Home or community vegetable gardens can be also an important action to combat malnutrition (SDG 2) by improving diet quality [71,72], as well as to achieve sustainable cities and communities (SDG 11) and better well-being of citizens (SDG 3) [73].

A case study on transportation of bread in UK promotes walking/cycling associated with consumers who need to buy bread from local bakeries as one of the main sustainable strategies associated with sustainable cities (SDG 12) and climate change (SDG 13) [74]. The rationale is behind the fact that an average shopping travel distance is above $750 \mathrm{~km} /$ year/household, with two-thirds of travelling carried out using a car.

Food loss and waste (SDG 12) occurring along the whole supply chain plays an important role in achieving sustainability and food security (SDG 2). For instance, Abbade [75] estimated that all the food lost globally could have fed 940 million adults in 2017. While it has been usually considered that household food waste is a key contributor in high-income countries [76], the FAO [77] recently reported that it is a general issue across all countries. Hence, understanding the social habits (i.e., food purchasing and kitchen management) and raising knowledge among household members are key actions to reduce food waste [78]. An interesting study was performed in the UK, pointing how developed countries deal with surplus food distribution as a tool to feed the hungry [79]. In spite of good will, the study revealed that a lack of legislation associated with food donation was an obstacle that cannot be ignored. A review of Lemaire and Limbourg [80] shed new light on existing approaches in reducing food loss and waste by highlighting the necessity of awareness raising among all stakeholders, and revealing needs for redesigning current and developing integrated supply chain models of redistribution, recovery and disposal. All presented efforts align with the need for achieving SDGs 2 and 12 and combating climate change (SDG 13).

\subsection{The Role of Other Food Supply Chain Stakeholders in Achieving UN SDGs \\ 3.5.1. Policymakers and Governments}

Policymakers and governments are key moderators that can impact food supply chains and set rules and legislation to achieve sustainable development. There are networks and collaborative frameworks that exist in the world that can impact food system transformation, such as the global urban agreement of Milan Urban Food Policy Pact or the upcoming UN Food Systems Summit. Such initiatives recommend key activities to accelerate the transition to sustainable food systems. These frameworks are primarily intended for national or local government departments. However, the integration of sustainability (and its goals) into food policy is a challenge [81], as it is hard to identify all policies due to 
food system complexity [6]. Moreover, Kanie and Biermann [82] highlighted that applying the SDGs within policies is "governing through goals", and countries can voluntarily report their achievements and no binding obligations are required [7]. Hence, this makes it difficult to analyze how the SDGs are implemented in domestic politics, and little research has assessed the level of integration. In this regard, only the article of Siegel and Bastos Lima [7] tackles this issues by evaluating how SDGs are included in policies of three South American countries (Brazil, Paraguay and Uruguay). Besides, only 47 countries worldwide have published the Voluntary National Review (VNR) on their level of achievement of SDGs [83]. A bottom-up approach in analyzing UN SDGs from a poultry food supply chain perspective in Brazil revealed obstacles such as environmental legislation not aligned with the SDGs, as well as diversity of business models applied, difficulties in measuring supply chain impacts and different engagement of the stakeholders [84].

National governments are responsible for establishing institutions and designing and implementing policies at the local or national level to develop food systems in line with national objectives and goals. Different stakeholders (e.g., civil society, private companies, research institutes, etc.) can help implement these policies and support governments in advancing a systemic transformation. All authorities should act as partners in improving processes and aligning the food supply chain to the motivation of achieving SDG 17. There is also a need to set better efforts in coordination with actors and integrate sustainability policies with other relevant ones in the food systems agenda (security, transportation, small and medium size enterprises, producers, etc.) at different levels, international to local [85].

\subsubsection{Inspection Services and Certification Bodies}

Different standards exist in the agribusiness sector, with mandatory requirements and related compliance procedures. These procedures can address aspects such as guidance on agricultural practices, requirements and standards for equipment supporting agricultural activities, seeds, plants, animal feeds, etc. Quality infrastructure (QI) and its impact on the Sustainable Development Goals (SDGs) is important in standardization, metrology, accreditation, testing, certification and inspection services. This quality infrastructure is fundamental in supporting this transformation to sustainable industry, smart processing and smart industry. The correct application of these standards ensures that food is fit and safe for consumption, which in turn allows people to live healthy lives and improve their social and economic well-being. An overview of technical committee ISO/TC 34 "Food products" [86] shows that this committee declares contributing to SDGs (SDGs 1, 2, 3, 5, 8, $10,11,12,13,15$ and 16) with published food-related standards.

Food safety standards such as Codex Alimentarius linked with good hygiene practice [87] and food safety management standards such as ISO 22000 [88], BRC [89] or IFS [90], along with various certification schemes outlined by the Global Food Safety Initiative (GFSI) [91], play a role in ensuring the health, safety and quality of food products. Production and distribution of safe food worldwide is directly linked to SDGs 2 and 3 but may also align with SDGs 9 and 12 [86]. However, the latest survey on the number of certified ISO 22000 companies worldwide shows below 35,000 issued certificates in less than 40,000 production sites [92]. Besides these standards, the implementation of environmental management systems (EMS) such as ISO 14001 [93] brings benefits in terms of aligning the life-cycle assessment approach (LCA) with SDG 13 [94]. This approach has emerged as an essential and widely recognized framework to understand and measure mainly environmental attributes but can be deployed to social and economic attributes of a product, material or process [95]. The LCA framework has been adopted by several familiar declarations, certifications, standards and regulatory requirements [96]. However, data show that below $0.5 \%$ of all certified EMS worldwide belong to the first two links of the supply chain-farming and food processing [92].

There are many inspection services and certification bodies in the world that provide laboratory testing, system certification, inspection and audit services against various standards. Their assessment are aligned with different conformity assessment standards such 
as ISO 17021 for bodies providing audit and certification of management systems [97] or ISO 17025 for laboratories [98]. Certification services cover quality, environment and safety management systems in sustainable development, food and green products, information technology as well as product certification and service certification.

When it comes to sustainability, there are numerous tools and approaches enabling greater awareness of sustainability importance and development, with corporate social responsibility (CSR) practice as the most recognized [99]. It promotes sustainability reporting using guidelines outlined by the Global Reporting Initiative (GRI) [100]. These guidelines (standards) are voluntary and refer to sustainability pillars-an organization's economic, environmental and social impacts [101]. Food companies reporting their indicators may strive towards efficient use of natural resources and reduction of environment impact [102]. Big corporations outline their connection with UN SDGs in their CRS reports such as Nestle [103]. Besides this, other sustainability assessment tools may help in calculating and reporting such as carbon and water foot printing, corporate sustainability reporting, sustainable claims support and sustainable packaging and evaluation, as promoted by some certification bodies [104]. In order to address global task to reduce greenhouse gas (GHG) emissions, governments, investors, stock exchanges and organizations have implemented reporting requirements and are pressuring businesses to reduce emissions throughout their value chain [105]. The approach is based on GHG protocols [106]. GHG emissions validation and verification may be used by food producers for a number of reasons, such as to contribute to their annual report, communicate to their customer, meet regulatory or investor reporting requirements or publicly disclose their emission reduction achievements. Independent validation and verification of GHG emissions for food organizations should comply with guidance aligned to ISO 14064 standards [107].

\subsubsection{Scientific Community}

The scientific community influences the education of food engineers and technology experts in sustainable development. More efforts are needed to ensure that research, education and scientific public communication are in line with sustainable development goals. The aim is setting directions and action lines for research projects to tackle some sustainable development goal and indicators. Universities play a key role in providing education that goes in accordance with sustainable development. In this regard, Kioupi and Voulvoulis [108] developed a framework to assess the alignment of 40 UK and European master's programs (related to environment and sustainability) to the SDGs. They reported the lack of some aspects (i.e., health, well-being, among others) within these educational programs and highlighted that universities must be aware of their contribution to sustainable development. Chaleta et al. [109] assessed the implementation of the SDGs in 187 undergraduate courses of the School of Social Sciences at the University of Évora, but no studies have specifically focused on food systems.

On the impact of sustainable development, a lot of efforts are needed to educate professionals to become sustainable food engineers and technologists, highlighting the need to impact SDG 4 and ensure inclusive and equitable quality education and promote lifelong learning opportunities for all. Education for SDGs with learning objectives are key facts to educate on different levels to form a generation of sustainability-oriented, green-thinking responsible citizens.

\subsubsection{Other Stakeholders}

Media has both a global and local role in communication toward consumers and other stakeholders in the food supply chain, where the impact of social media is increasing $[110,111]$. Regarding the UN SDGs, the United Nations launched their Media Compact campaign, including 100 members reaching to an audience of about 2 billion people in 160 countries across five continents, mainly by disseminating facts, stories and solutions [112]. For the food supply chain, the main focus of the media should be on SDGs 12, 13 and 17 with instructions, examples and success stories that each individual can relate to. Academia, 
though its interdisciplinary, inter-institutional communication with support of the media, can build a better future and assure safe, healthy and sustainable food processing and production. Besides media, NGOs also play a role in achieving their commitment "to leave no one behind", promoting the practical contributions of civil society in achieving UN SDGs, as agreed by more than 100 contributors [113].

\subsubsection{Practical Implications and Future Steps}

This overview provides a new perspective on the role of primary and secondary stakeholders of the food supply chain in fulfilling UN SDGs. Although a certain amount of attention is given to the correlation between UN SDGs and food supply chains, their deployment to specific goals on a global level or to specific food sectors is still at a low to moderate level in terms of their acknowledgement and food-sector application. Despite the considerable attention paid to some UN SDGs ("Zero Hunger", "Responsible Consumption and Production" and "Climate Action"), the majority of other directly or indirectly related UN SDGs are still under the radar and few studies have integrated all of them in a holistic approach. Our findings specify focus points for both primary and secondary stakeholders enabling better understanding of the intertwining of UN SDGs and food supply chains. Elevating the perspective to countries, it is obvious that developing countries have different challenges compared to the developed countries, and therefore, national strategies are diverse, as outlined during the 2021 Food Systems Pre-Summit held in Rome in July 2021 [2].

Results of this study provide a new dimension for managers, agronomists, food technologists, food traders and environmental/sustainability scientists in understanding their impacts on UN SDGs engaged in the supply chain. Key points of the discussion can also be helpful to other stakeholders such as academia or policymakers who intend to further explore potential means of supporting the achievement of UN SDGs. In parallel, they can assist in decision-making and/or recommendations when mitigation strategies need to be employed.

Similar to the existence of guides associated to good hygiene and/or manufacturing practices throughout the food supply chain published either as standards [87] or legislation [114], the authors believe that similar guides for the UN SDGs should be developed in the near future. All the theoretical background should be deployed in three main directions: (i) guides for fulfillment of each of the 17 UN SDGs applicable in the food supply chain; (ii) guides for specific food sectors such as meat, dairy or cereal chains, (iii) special attention should be put on drafting simple guides for small and medium-sized enterprises.

\section{Concluding Remarks}

Food systems are crucial in achieving the UN SDGs, and previous studies mostly focused on the contribution of food systems to SDG2. In this regard, the novelty of this overview is to give attention to the key stakeholders and discuss their influence on the achievement of all SDGs, directly or indirectly. Figure 3 summarizes all these contributions, as discussed in the previous sections. In addition, the interlinkage between the different actors is based on strengthening partnerships for the goals (SDG 17). Considering all actors, the system tackles all SDGs, but the most prevailing goals are the SDGs 2 and 12. This is not unexpected, since they are the two key food-related SDGs. 


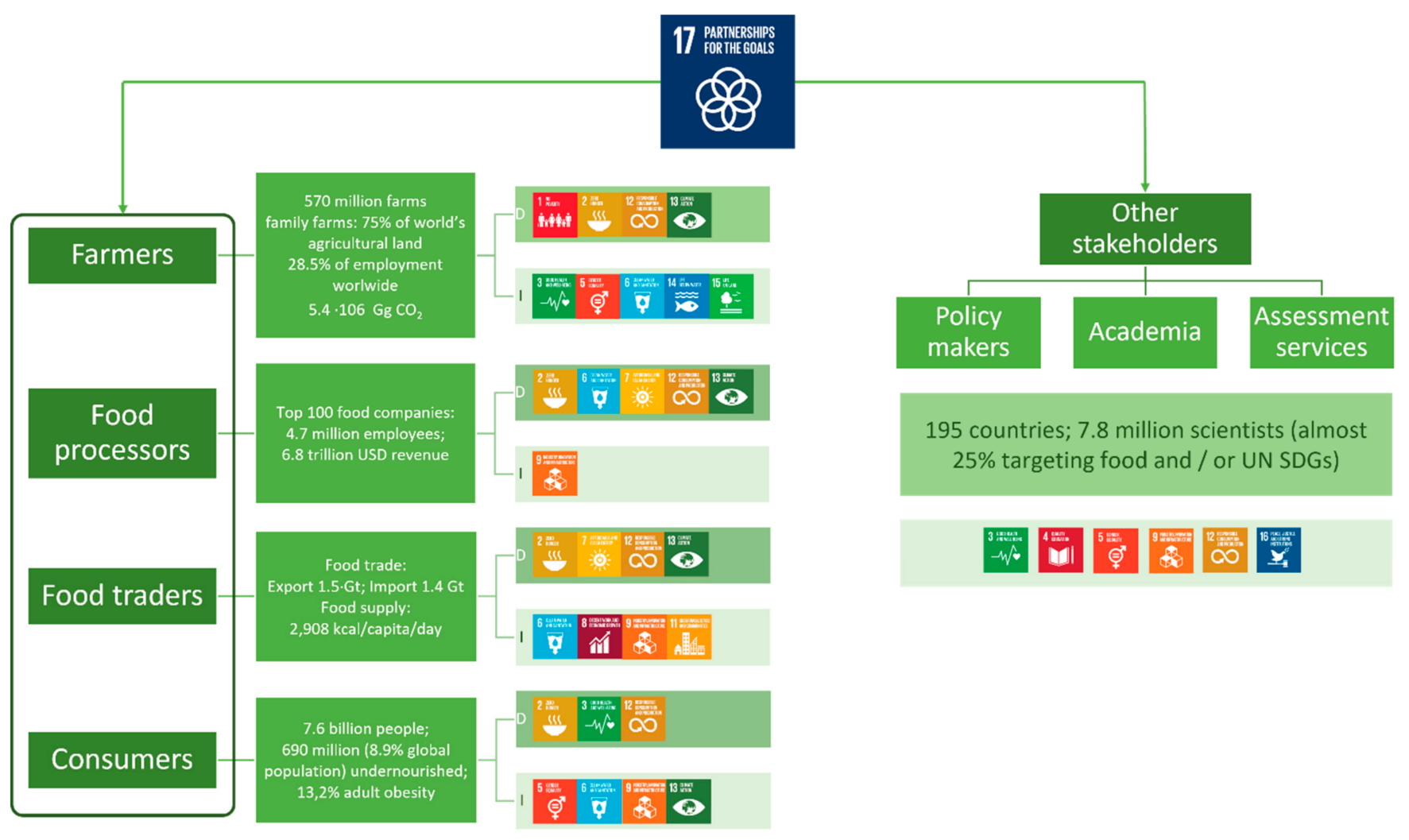

Figure 3. Food supply chain, facts and figures and UN sustainable development goals [20,77,115-118]. Legend: D—direct correlation with an SDG; I-indirect correlation with an SDG.

This study has two main limitations. The first is the fact that it was not written as a review paper, but rather as an overview providing insight from both literature and expertise of the authors. The second limitation is the fact that approaches of other scholars towards UN SDGs are very picturesque in terms of creativity and approach, so some of these ideas have not been included in this overview. A key challenge of this study was the lack of data on the level of achievement of the SDGs, and most difficult was relating it with different stakeholders. In this regard, the FAO recently published some indicators, since it will be the responsible body to report on the 21 SDG indicators of SDGs 2, 5, 6, 12, 14 and 15 [119]. Nevertheless, further investigation is needed to assess the current impact of stakeholders on SDGs, as well as the potential effect when implementing innovations in any step of the food supply chain. This will allow us to set action lines and work together to achieve the SDGs.

Supplementary Materials: The following are available online at https:/ /www.mdpi.com/article/10 $.3390 /$ su13169095/s1.

Author Contributions: Conceptualization, I.D. and A.R.J.; Methodology, I.D.; formal analysis, all authors; investigation, all authors; writing—original draft preparation, I.D.; writing—review and editing, all authors. All authors have read and agreed to the published version of the manuscript.

Funding: This research received no external funding.

Data Availability Statement: Not applicable.

Acknowledgments: Laura Batlle-Bayer, Alba Bala and Pere Fullana-i-Palmer thank the Spanish Ministry of Science and Competitiveness for their support via the KAIROS-BIOCIR Project PID2019104925RB-C33 (AEO/FEDER, UE). The authors are responsible for the choice and presentation of information contained in this paper as well as for the opinions expressed therein, which are not necessarily those of UNESCO and do not commit this Organization.

Conflicts of Interest: The authors declare no conflict of interest. 


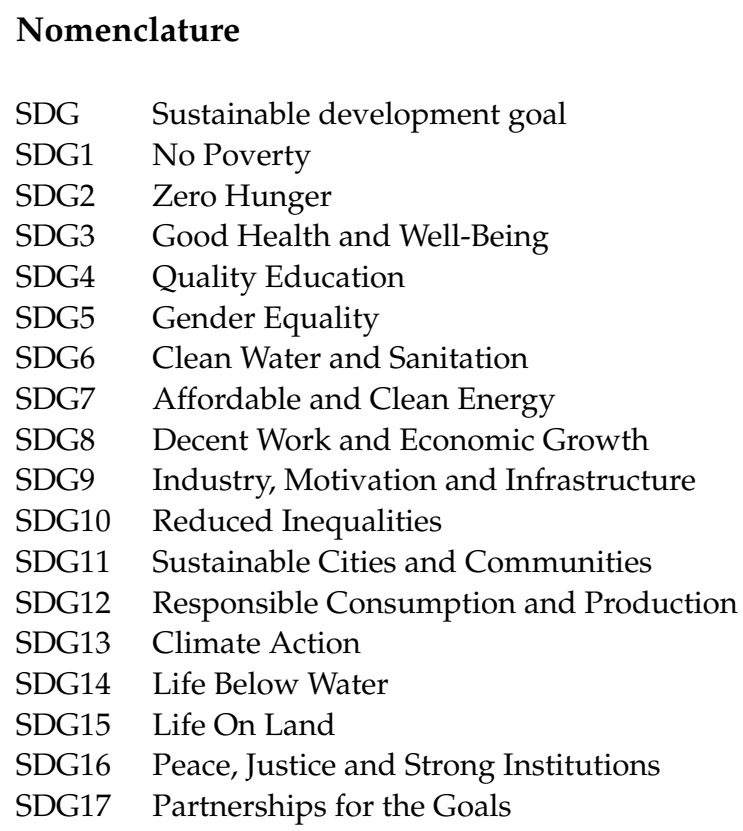

\section{References}

1. UN. Transforming our World: The 2030 Agenda for Sustainable Development; United Nations: New York, NY, USA, 2016.

2. UN. More Than 100 Countries Discuss Visions for National food Futures to Accelerate Global Action Ahead of September Summit. Available online: https://www.un.org/en/food-systems-summit/news/more-100-countries-discuss-visions-national-foodfutures-accelerate-global (accessed on 1 July 2021).

3. UN. About the Summit. Available online: http://unstats.un.org/unsd/methods/m49/m49regin.htm (accessed on $1 \mathrm{July} 2021$ ).

4. FAO. FAO and the 17 Sustainable Development Goals; Food and Agriculture Organization of the United Nations \& World Health Organization: Rome, Italy, 2015.

5. Herrero, M.; Thornton, P.K.; Mason-D’Croz, D.; Palmer, J.; Bodirsky, B.L.; Pradhan, P.; Barrett, C.B.; Benton, T.G.; Hall, A.; Pikaar, I.; et al. Articulating the effect of food systems innovation on the Sustainable Development Goals. Lancet Planet. Health 2021, 5 , e50-e62. [CrossRef]

6. Brown, K.A.; Srinivasapura Venkateshmurthy, N.; Law, C.; Harris, F.; Kadiyala, S.; Shankar, B.; Mohan, S.; Prabhakaran, D.; Knai, C. Moving towards sustainable food systems: A review of Indian food policy budgets. Glob. Food Secur. 2021, 28, 100462. [CrossRef]

7. Siegel, K.M.; Bastos Lima, M.G. When international sustainability frameworks encounter domestic politics: The sustainable development goals and agri-food governance in South America. World Dev. 2020, 135, 105053. [CrossRef]

8. Bizikova, L.; Jungcurt, S.; McDougal, K.; Tyler, S. How can agricultural interventions enhance contribution to food security and SDG 2.1? Glob. Food Secur. 2020, 26, 100450. [CrossRef]

9. Blesh, J.; Hoey, L.; Jones, A.D.; Friedmann, H.; Perfecto, I. Development pathways toward “zero hunger". World Dev. 2019, 118, 1-14. [CrossRef]

10. Gamboa, G.; Kovacic, Z.; Di Masso, M.; Mingorría, S.; Gomiero, T.; Rivera-Ferré, M.; Giampietro, M. The complexity of food systems: Defining relevant attributes and indicators for the evaluation of food supply chains in Spain. Sustainability 2016, 8, 515. [CrossRef]

11. Carbone, A. Food supply chains: Coordination governance and other shaping forces. Agric. Food Econ. 2017, 5, 3. [CrossRef]

12. Djekic, I.; Tomasevic, I. Role of Sustainable Quality in the Food Chain. In Zero Hunger; Leal Filho, W., Azul, A.M., Brandli, L., Özuyar, P.G., Wall, T., Eds.; Springer International Publishing: Cham, Switzerland, 2020. [CrossRef]

13. Minnens, F.; Lucas Luijckx, N.; Verbeke, W. Food supply chain stakeholders' perspectives on sharing information to detect and prevent food integrity issues. Foods 2019, 8, 225. [CrossRef] [PubMed]

14. Rebs, T.; Brandenburg, M.; Seuring, S.; Stohler, M. Stakeholder influences and risks in sustainable supply chain management: A comparison of qualitative and quantitative studies. Bus. Res. 2018, 11, 197-237. [CrossRef]

15. Sodhi, M.S.; Tang, C.S. Corporate social sustainability in supply chains: A thematic analysis of the literature. Int. J. Prod. Res. 2018, 56, 882-901. [CrossRef]

16. Heiko, A. Consensus measurement in Delphi studies: Review and implications for future quality assurance. Technol. Forecast. Soc. Chang. 2012, 79, 1525-1536.

17. Batlle-Bayer, L.; Bala, A.; Albertí, J.; Xifré, R.; Aldaco, R.; Fullana-i-Palmer, P. Food affordability and nutritional values within the functional unit of a food LCA. An application on regional diets in Spain. Resour. Conserv. Recycl. 2020, 160, 104856. [CrossRef]

18. Clark, M.; Tilman, D. Comparative analysis of environmental impacts of agricultural production systems, agricultural input efficiency, and food choice. Environ. Res. Lett. 2017, 12, 064016. [CrossRef] 
19. Shukla, P.; Skea, J.; Calvo Buendia, E.; Masson-Delmotte, V.; Pörtner, H.; Roberts, D.; Zhai, P.; Slade, R.; Connors, S.; Van Diemen, R. Climate Change and Land: An IPCC Special Report on Climate Change, Desertification, Land Degradation, Sustainable Land Management, Food Security, and Greenhouse Gas Fluxes in Terrestrial Ecosystems; IPCC: Geneva, Switzerland, 2019.

20. Lowder, S.K.; Skoet, J.; Raney, T. The number, size, and distribution of farms, smallholder farms, and family farms worldwide. World Dev. 2016, 87, 16-29. [CrossRef]

21. FAO. The Future of Food and Agriculture: Trends and Challenges; Food and Agriculture Organization of the United Nations: Rome, Italy, 2017.

22. Arouna, A.; Lokossou, J.; Wopereis, M.; Bruce-Oliver, S.; Roy-Macauley, H. Contribution of improved rice varieties to poverty reduction and food security in sub-Saharan Africa. Glob. Food Secur. 2017, 14, 54-60. [CrossRef]

23. Thornton, P.K.; Kristjanson, P.; Förch, W.; Barahona, C.; Cramer, L.; Pradhan, S. Is agricultural adaptation to global change in lower-income countries on track to meet the future food production challenge? Global Environ. Chang. 2018, 52, 37-48. [CrossRef]

24. Runzel, M.A.; Hassler, E.E.; Rogers, R.; Formato, G.; Cazier, J.A. Designing a smart honey supply chain for sustainable development. IEEE Consum. Electron. Mag. 2021, 10, 69-78. [CrossRef]

25. Clark, M.A.; Domingo, N.G.; Colgan, K.; Thakrar, S.K.; Tilman, D.; Lynch, J.; Azevedo, I.L.; Hill, J.D. Global food system emissions could preclude achieving the $1.5^{\circ}$ and $2^{\circ} \mathrm{C}$ climate change targets. Science 2020, 370, 705-708. [CrossRef]

26. IPCC. Climate change 2013: The physical science basis. In Report of the Intergovernmental Panel on Climate Change; Stocker, T.F., Qin, D., Plattner, G.-K., Tignor, M., Allen, S.K., Boschung, J., Nauels, A., Xia, Y., Bex, V., Midgley, P.M., Eds.; Cambridge University Press Cambridge: Cambridge, UK, 2013.

27. Challinor, A.J.; Watson, J.; Lobell, D.B.; Howden, S.; Smith, D.; Chhetri, N. A meta-analysis of crop yield under climate change and adaptation. Nat. Clim. Chang. 2014, 4, 287-291. [CrossRef]

28. Ali, A.; Erenstein, O. Assessing farmer use of climate change adaptation practices and impacts on food security and poverty in Pakistan. Clim. Risk Manag. 2017, 16, 183-194. [CrossRef]

29. Khanal, U.; Wilson, C.; Rahman, S.; Lee, B.L.; Hoang, V.-N. Smallholder farmers' adaptation to climate change and its potential contribution to UN's sustainable development goals of zero hunger and no poverty. J. Clean. Prod. 2021, 281, 124999. [CrossRef]

30. Charoenratana, S.; Shinohara, C. Rural farmers in an unequal world: Land rights and food security for sustainable well-being Land Use Policy 2018, 78, 185-194. [CrossRef]

31. Villano, R.; Asante, B.O.; Bravo-Ureta, B. Farming systems and productivity gaps: Opportunities for improving smallholder performance in the forest-savannah transition zone of Ghana. Land Use Policy 2019, 82, 220-227. [CrossRef]

32. Rashid, F.N. ACHIEVING SDGs in TANZANIA: Is there a nexus between land tenure SECURITY, agricultural credits and rice PRODUCTIVITY? Resour. Conserv. Recycl. 2021, 164, 105216. [CrossRef]

33. Agarwal, B. Gender equality, food security and the sustainable development goals. Curr. Opin. Environ. Sustain. 2018, 34, 26-32. [CrossRef]

34. Meneses, Y.E.; Stratton, J.; Flores, R.A. Water reconditioning and reuse in the food processing industry: Current situation and challenges. Trends Food Sci. Technol. 2017, 61, 72-79. [CrossRef]

35. Djekic, I.; Tomasevic, I. Role of Potable Water in Food Processing. In Clean Water and Sanitation; Leal Filho, W., Azul, A.M., Brandli, L., Lange Salvia, A., Wall, T., Eds.; Springer International Publishing: Cham, Switzerland, 2020. [CrossRef]

36. Spada, A.; Conte, A.; Del Nobile, M.A. The influence of shelf life on food waste: A model-based approach by empirical market evidence. J. Clean. Prod. 2018, 172, 3410-3414. [CrossRef]

37. Jambrak, A.R. Non-thermal and Innovative Processing Technologies. In Encyclopedia of Food Security and Sustainability; Ferranti, P., Berry, E.M., Anderson, J.R., Eds.; Elsevier: Oxford, UK, 2019; pp. 477-483. [CrossRef]

38. Režek Jambrak, A.; Nutrizio, M.; Djekić, I.; Pleslić, S.; Chemat, F. Internet of Nonthermal Food Processing Technologies (IoNTP): Food Industry 4.0 and Sustainability. Appl. Sci. 2021, 11, 686. [CrossRef]

39. Meng, Y.; Yang, Y.; Chung, H.; Lee, P.-H.; Shao, C. Enhancing sustainability and energy efficiency in smart factories: A review. Sustainability 2018, 10, 4779. [CrossRef]

40. Augustin, M.A.; Riley, M.; Stockmann, R.; Bennett, L.; Kahl, A.; Lockett, T.; Osmond, M.; Sanguansri, P.; Stonehouse, W.; Zajac, I.; et al. Role of food processing in food and nutrition security. Trends Food Sci. Technol. 2016, 56, 115-125. [CrossRef]

41. Janssens, C.; Havlík, P.; Krisztin, T.; Baker, J.; Frank, S.; Hasegawa, T.; Leclère, D.; Ohrel, S.; Ragnauth, S.; Schmid, E. Global hunger and climate change adaptation through international trade. Nat. Clim. Chang. 2020, 10, 829-835. [CrossRef]

42. Brown, M.E.; Carr, E.R.; Grace, K.L.; Wiebe, K.; Funk, C.C.; Attavanich, W.; Backlund, P.; Buja, L. Do markets and trade help or hurt the global food system adapt to climate change? Food Policy 2017, 68, 154-159. [CrossRef]

43. Wang, T.; Qu, Z.; Yang, Z.; Nichol, T.; Clarke, G.; Ge, Y.-E. Climate change research on transportation systems: Climate risks, adaptation and planning. Transp. Res. Part D Transport. Environ. 2020, 88, 102553. [CrossRef]

44. Boarnet, M.G. Planning, climate change, and transportation: Thoughts on policy analysis. Transp. Res. Part A Policy Pract. 2010, 44, 587-595. [CrossRef]

45. Coley, D.; Howard, M.; Winter, M. Local food, food miles and carbon emissions: A comparison of farm shop and mass distribution approaches. Food Policy 2009, 34, 150-155. [CrossRef]

46. Leopold. Calculating Food Miles for a Multiple Ingredient Food Product; Agriculture, L.C.f.S., Ed.; Iowa State University: Ames, IA, USA, 2005. 
47. Payen, S.; Basset-Mens, C.; Perret, S. LCA of local and imported tomato: An energy and water trade-off. J. Clean. Prod. 2015, 87, 139-148. [CrossRef]

48. Farmery, A.K.; Gardner, C.; Green, B.S.; Jennings, S.; Watson, R.A. Domestic or imported? An assessment of carbon footprints and sustainability of seafood consumed in Australia. Environ. Sci. Policy 2015, 54, 35-43. [CrossRef]

49. Schmitt, E.; Galli, F.; Menozzi, D.; Maye, D.; Touzard, J.-M.; Marescotti, A.; Six, J.; Brunori, G. Comparing the sustainability of local and global food products in Europe. J. Clean. Prod. 2017, 165, 346-359. [CrossRef]

50. Djekic, I.; Tomasevic, I. Impact of animal origin food production on climate change and vice versa: Analysis from a meat and dairy products perspective. In Handbook of Climate Change Management: Research, Leadership, Transformation; Leal Filho, W., Luetz, J., Ayal, D., Eds.; Springer International Publishing: Cham, Switzerland, 2020; pp. 1-16. [CrossRef]

51. Sofos, J.N. Chapter 6-Meat and Meat Products. In Food Safety Management; Lelieveld, Y.M., Ed.; Academic Press: Cambridge, MA, USA, 2014; pp. 119-162. [CrossRef]

52. Baldera Zubeldia, B.; Nieto Jiménez, M.; Valenzuela Claros, M.T.; Mariscal Andrés, J.L.; Martin-Olmedo, P. Effectiveness of the cold chain control procedure in the retail sector in Southern Spain. Food Control 2016, 59, 614-618. [CrossRef]

53. Djekic, I.; Tomasevic, I. Environmental impacts of the meat chain-Current status and future perspectives. Trends Food Sci. Technol. 2016, 54, 94-102. [CrossRef]

54. Hart, M.; Austin, W.; Acha, S.; Le Brun, N.; Markides, C.N.; Shah, N. A roadmap investment strategy to reduce carbon intensive refrigerants in the food retail industry. J. Clean. Prod. 2020, 275, 123039. [CrossRef]

55. Jouzdani, J.; Govindan, K. On the sustainable perishable food supply chain network design: A dairy products case to achieve sustainable development goals. J. Clean. Prod. 2021, 278, 123060. [CrossRef]

56. Burek, J.; Nutter, D.W. Environmental implications of perishables storage and retailing. Renew. Sustain. Energy Rev. 2020, 133, 110070. [CrossRef]

57. James, C. Chapter 13-Food transportation and refrigeration technologies-Design and optimization. In Sustainable Food Supply Chains; Accorsi, R., Manzini, R., Eds.; Academic Press: Cambridge, MA, USA, 2019; pp. 185-199. [CrossRef]

58. ISO. ISO 14020:2000 Environmental Labels and Declarations-General Principles; International Organization for Standardization: Geneva, Switzerland, 2000.

59. ISO. ISO 14026:2017 Environmental Labels and Declarations_Principles, Requirements and Guidelines for Communication of Footprint Information; International Organization for Standardization: Geneva, Switzerland, 2017.

60. Kaczorowska, J.; Rejman, K.; Halicka, E.; Szczebyło, A.; Gorska-Warsewicz, H. Impact of food sustainability labels on the perceived product value and price expectations of urban consumers. Sustainability 2019, 11, 7240. [CrossRef]

61. Asioli, D.; Aschemann-Witzel, J.; Nayga, R.M., Jr. Sustainability-related food labels. Annu. Rev. Resour. Econ. 2020, 12, 171-185. [CrossRef]

62. De Bauw, M.; Matthys, C.; Poppe, V.; Vranken, L. A combined Nutri-Score and 'Eco-Score'Approach for more Nutritious and more Environmentally Friendly Food Choices? Evidence From a Belgian Consumer Experiment. Food Qual. Prefer. 2021, 93, 104276. [CrossRef]

63. Ecolabel. All Ecolables. Available online: http://www.ecolabelindex.com/ecolabels/ (accessed on 10 March 2021).

64. FAO/WHO. Sustainable Healthy Diets—Guiding Principles; Food and Agriculture Organization of the United Nations \& World Health Organization: Rome, Italy, 2019.

65. Tilman, D.; Clark, M. Global diets link environmental sustainability and human health. Nature 2014, 515, 518-522. [CrossRef]

66. Abejón, R.; Batlle-Bayer, L.; Laso, J.; Bala, A.; Vazquez-Rowe, I.; Larrea-Gallegos, G.; Margallo, M.; Cristobal, J.; Puig, R.; Fullana-i-Palmer, P. Multi-Objective Optimization of Nutritional, Environmental and Economic Aspects of Diets Applied to the Spanish Context. Foods 2020, 9, 1677. [CrossRef]

67. Batlle-Bayer, L.; Aldaco, R.; Bala, A.; Fullana-i-Palmer, P. Toward sustainable dietary patterns under a water-energy-food nexus life cycle thinking approach. Curr. Opin. Environ. Sci. Health 2020, 13, 61-67. [CrossRef]

68. Willett, W.; Rockström, J.; Loken, B.; Springmann, M.; Lang, T.; Vermeulen, S.; Garnett, T.; Tilman, D.; DeClerck, F.; Wood, A. Food in the Anthropocene: The EAT-Lancet Commission on healthy diets from sustainable food systems. Lancet 2019, 393, 447-492. [CrossRef]

69. Springmann, M.; Spajic, L.; Clark, M.A.; Poore, J.; Herforth, A.; Webb, P.; Rayner, M.; Scarborough, P. The healthiness and sustainability of national and global food based dietary guidelines: Modelling study. BMJ 2020, 370, m2322. [CrossRef] [PubMed]

70. Huang, Y.; Tian, X. Food accessibility, diversity of agricultural production and dietary pattern in rural China. Food Policy 2019, 84, 92-102. [CrossRef]

71. Schreinemachers, P.; Patalagsa, M.A.; Islam, M.R.; Uddin, M.N.; Ahmad, S.; Biswas, S.C.; Ahmed, M.T.; Yang, R.-Y.; Hanson, P.; Begum, S. The effect of women's home gardens on vegetable production and consumption in Bangladesh. Food Secur. 2015, 7 , 97-107. [CrossRef]

72. Pradhan, A.; Sathanandhan, R.; Panda, A.K.; Wagh, R. Improving household diet diversity through promotion of nutrition gardens in India. Am. J. Food Sci. Nutr. 2018, 5, 43-51.

73. Ambrose, G.; Das, K.; Fan, Y.; Ramaswami, A. Is gardening associated with greater happiness of urban residents? A multi-activity, dynamic assessment in the Twin-Cities region, USA. Landsc. Urban Plan. 2020, 198, 103776. [CrossRef]

74. López-Avilés, A.; Veldhuis, A.J.; Leach, M.; Yang, A. Sustainable energy opportunities in localised food production and transportation: A case study of bread in the UK. Sustain. Prod. Consum. 2019, 20, 98-116. [CrossRef] 
75. Abbade, E.B. Estimating the nutritional loss and the feeding potential derived from food losses worldwide. World Dev. 2020, 134, 105038. [CrossRef]

76. Gustavsson, J.; Cederberg, C.; Sonesson, U.; van Otterdijk, R.; Meybeck, A. Global Food Losses and Food Waste: Extent, Causes and Prevention; FAO: Rome, Italy, 2011.

77. FAO. The State of Food Security and Nutrition in the World 2020. Transforming Food Systems for Affordable Healthy Diet; International Fund for Agricultural Development (IFAD), WFP, WHO, Eds.; Food and Agriculture Organization of the United Nations: Rome, Italy, 2020.

78. Djekic, I.; Miloradovic, Z.; Djekic, S.; Tomasevic, I. Household food waste in Serbia-Attitudes, quantities and global warming potential. J. Clean. Prod. 2019, 229, 44-52. [CrossRef]

79. Thapa Karki, S.; Bennett, A.C.T.; Mishra, J.L. Reducing food waste and food insecurity in the UK: The architecture of surplus food distribution supply chain in addressing the sustainable development goals (Goal 2 and Goal 12.3) at a city level. Ind. Mark. Manag. 2021, 93, 563-577. [CrossRef]

80. Lemaire, A.; Limbourg, S. How can food loss and waste management achieve sustainable development goals? J. Clean. Prod. 2019, 234, 1221-1234. [CrossRef]

81. Sachs, J.D.; Schmidt-Traub, G.; Mazzucato, M.; Messner, D.; Nakicenovic, N.; Rockström, J. Six transformations to achieve the sustainable development goals. Nat. Sustain. 2019, 2, 805-814. [CrossRef]

82. Kanie, N.; Biermann, F. Governing Through Goals: Sustainable Development Goals as Governance Innovation; MIT Press: Cambridge, MA, USA, 2017.

83. OHCHR. Voluntary National Reviews. Available online: https://www.ohchr.org/EN/Issues/SDGS/Pages/2020VoluntaryNationalReviews. aspx (accessed on 12 April 2021).

84. Pohlmann, C.R.; Scavarda, A.J.; Alves, M.B.; Korzenowski, A.L. The role of the focal company in sustainable development goals: A Brazilian food poultry supply chain case study. J. Clean. Prod. 2020, 245, 118798. [CrossRef]

85. Djekic, I.; Sanjuán, N.; Clemente, G.; Jambrak, A.R.; Djukić-Vuković, A.; Brodnjak, U.V.; Pop, E.; Thomopoulos, R.; Tonda, A. Review on environmental models in the food chain-Current status and future perspectives. J. Clean. Prod. 2018, 176, 1012-1025. [CrossRef]

86. ISO. ISO/TC 34 Food Products. Available online: https://www.iso.org/committee/47858.html (accessed on 15 March 2021).

87. CAC. CAC/RCP 1-1969, Rev.4-2003. Recommended International Code of Practice—General Principles of Food Hygiene Codex Alimentarius Commission; Food and Agriculture Organization: Rome, Italy, 2003.

88. ISO. ISO 22000:2018 Food Safety Management Systems—Requirements for Any Organization in the Food Chain; International Organization for Standardization: Geneva, Switzerland, 2018.

89. BRC. BRC Global Standard for Food Safety, Issue 8; BRC Trading Ltd.: London, UK, 2018.

90. IFS. IFS Food, version 6.1. IFS Management GmbH: Berlin, Germany, 2017.

91. GFSI. GFSI. GFSI recognized certification programme owners. In Progress Benchmark E TE Applications List-April 2020; Global Food Safety Inititative \& The Consumer Goods Forum: Levallois-Perret, France, 2020.

92. ISO. The ISO Survey of Certifications 2019; International Organization for Standardization: Geneva, Switzerland, 2020.

93. ISO. ISO 14001:2015 Environmental Management Systems-Requirements with Guidance for Use; International Organization for Standardization: Geneva, Switzerland, 2015.

94. ISO. ISO/TC 207 Environmental Management. Available online: https:/ / www.iso.org/committee/54808.html (accessed on 15 March 2021).

95. ISO. ISO 14040:2006 Environmental Management_Life Cycle Assessment_Principles and Framework; International Organization for Standardization: Geneva, Switzerland, 2006.

96. Espinoza-Orias, N.; Stichnothe, H.; Azapagic, A. The carbon footprint of bread. Int. J. Life Cycle Assess. 2011, 16, 351-365. [CrossRef]

97. ISO. ISO/IEC 17021-1:2015 Conformity assessment-Requirements for Bodies Providing Audit and Certification of Management SystemsPart 1: Requirements; International Organization for Standardization: Geneva, Switzerland, 2015.

98. ISO. ISO/IEC 17025:2017 General Requirements for the Competence of Testing and Calibration Laboratories; International Organization for Standardization: Geneva, Switzerland, 2017.

99. Lozano, R. Analysing the use of tools, initiatives, and approaches to promote sustainability in corporations. Corp. Soc. Responsib. Environ. Manag. 2019, 27, 982-998. [CrossRef]

100. Lozano, R. Towards better embedding sustainability into companies' systems: An analysis of voluntary corporate initiatives. J. Clean. Prod. 2012, 25, 14-26. [CrossRef]

101. GRI. About GRI. Available online: https:/ / www.globalreporting.org/about-gri/ (accessed on 11 December 2020).

102. Maloni, M.J.; Brown, M.E. Corporate Social Responsibility in the Supply Chain: An Application in the Food Industry. J. Bus. Ethics 2006, 68, 35-52. [CrossRef]

103. Nestle. Nestlé in Society. Creating Shared Value and Meeting our Commitments 2017; Nestec S.A.: Vevey, Switzerland, 2018.

104. Intertek. Sustainability Assurance. Available online: https://www.intertek.com/sustainability/assurance/ (accessed on 12 March 2021).

105. De Menna, F.; Vittuari, M.; Molari, G. Impact evaluation of integrated food-bioenergy systems: A comparative LCA of peach nectar. Biomass Bioenergy 2015, 73, 48-61. [CrossRef] 
106. GHG. The greenhouse gas protocol. In A Corporate Accounting and Reporting Standard; World Resources Institute and World Business Council for Sustainable Development: Amsterdam, The Netherlands, 2015.

107. ISO. ISO 14064-1:2018 Greenhouse Gases_Part 1: Specification with Guidance at the Organization Level for Quantification and Reporting of Greenhouse Gas Emissions and Removals; International Organization for Standardization: Geneva, Switzerland, 2018.

108. Kioupi, V.; Voulvoulis, N. Sustainable Development Goals (SDGs): Assessing the Contribution of Higher Education Programmes. Sustainability 2020, 12, 6701. [CrossRef]

109. Chaleta, E.; Saraiva, M.; Leal, F.; Fialho, I.; Borralho, A. Higher Education and Sustainable Development Goals (SDG)—Potential Contribution of the Undergraduate Courses of the School of Social Sciences of the University of Évora. Sustainability 2021, 13, 1828. [CrossRef]

110. Elghannam, A.; Mesias, F. Short food supply chains from a social media marketing perspective: A consumer-oriented study in Spain. New Medit Mediterr. J. Econ. Agric. Environ. = Rev. Méditerr. d'Econ. Agric. et Environ. 2019, 18. [CrossRef]

111. Singh, A.; Shukla, N.; Mishra, N. Social media data analytics to improve supply chain management in food industries. Transp. Res. Part E Logist. Transp. Rev. 2018, 114, 398-415. [CrossRef]

112. UN. United Nations SDG Media Compact Hits 100-Member Mark; United Nations: New York, NY, USA, 2020.

113. UN. Non-Governmental Organizations (NGO) Major Group-Official Position Paper for the 2017 High-Level Political Forum. In Full Position Paper of the Non-Governmental Organizations (NGO) Major Group; Group, N.M., Ed.; United Nations: San Francisco, CA, USA, 2017.

114. FSA. Guide to Food Hygiene \& Other Regulations for the UK Meat Industry; Guide, M.I., Ed.; Food Standards Agency: London, UK, 2013.

115. FAOSTAT. Food and Agriculture Data. Available online: http://www.fao.org/faostat/en/\#home (accessed on 12 March 2021).

116. UNESCO. UNESCO Science Report: Towards 2030; United Nations Educational, Scientific and Cultural Organization: Paris, France, 2015.

117. TWB. Employment in Agriculture (\% of Total Employment)—Modeled ILO Estimate. Available online: https:/ / data.worldbank. org/indicator/SL.AGR.EMPL.ZS?end=2019\&start=1991 (accessed on 22 May 2021).

118. Laughman, C. The 2020 Top 100 Food \& Beverage Companies. In Food Engineering; E-Magazine: Troy, MI, USA, 2021.

119. FAO. Sustainable Development Goals—Indicators under FAO Custodianship. Available online: http://www.fao.org/sustainabledevelopment-goals/indicators/en/ (accessed on 12 April 2021). 